\title{
Evaluation of the macronutrients composition of soil, leaves and seeds of African yam bean (Sphenostylis sternocarpa harms)
}

\author{
O.A. OLAYIWOLA ${ }^{1}$, D. F. LATONA ${ }^{1}$, G.O. OYELEKE ${ }^{2}$ \\ ${ }^{I}$ DEPARTMENT OF APPLIED SCIENCES, OSUN STATE POLYTECHNIC, IREE \\ OSUN STATE, NIGERIA \\ ${ }^{2}$ DEPARTMENT OF SCIENCE LABORATORY TECHNOLOGY, OSUN STATE POLYTECHNIC, \\ IREE, OSUN STATE, NIGERIA
}

\begin{abstract}
The level of macronutrients (nitrogen, phosphorus, potassium, calcium and magnesium) in African yam bean (Spheostylisnsternocarpa harms) collected at Ede (latitude $7^{\circ} 44.952^{\prime} \mathrm{N}$ and longititude $4^{\circ} 26.114^{\prime} E$, elevation of 271.8m) in Osun State Nigeria, was investigated by studying the levels of nitrogen, phosphorus, potassium, calcium and magnesium in soil, leaves and the seed using standard methods. The highest level of nitrogen was obtained in the mature seed $(3.37 \pm 0.26 \%)$; soil sample had the highest phosphorus concentration $(334 \pm 10 \mathrm{mg} / \mathrm{kg})$. Leaves had the highest potassium, calcium and magnesium concentration $(11056 \pm 10 \mathrm{mg} / \mathrm{kg}, 6576 \pm 19 \mathrm{mg} / \mathrm{kg}$ and $1547 \pm 30 \mathrm{mg} / \mathrm{kg}$ respectively). The relative availability of nitrogen in the samples was seed > leaves > soil, for phosphorus, soil > leaves > seeds, for potassium, leaves > soil > seeds, for calcium, leaves > soil > seeds and magnesium, leaves >seeds > soil. Statistical analysis reveals a positive correlation of the macronutrients between leaves/seed except for nitrogen leaves/nitrogen seed $(r=-0.545)$ at $p<0.01$. Significance difference was observed in the means of the macronutrients for samples analyzed at $p<0.05$. African yam bean has the potential of boosting the nutrition of the greatest number of needful Africans.
\end{abstract}

Keywords: African yam bean, Assessment, Leaves, Macronutrient, Soil.

\section{Introduction}

The African yam bean (S. stenocarpa) is a proteinous plant of promise. Its current status as a minor crop suggests that this potential is largely under-exploited. Hence, research efforts are required to improve its agronomic characteristics and promote its cultivation as a major crop [1, 2]. The consumption of whole plant foods slows digestion and allows better absorption and a more favourable balance of essential nutrients per calorie, resulting in better management of cell growth, maintenance and mitosis (cell division) as well as better regulation of appetite and blood sugar [2,3]. One study in China found some regions had essentially no cancer or heart disease, while other areas they reflected "up to a 100- fold increase" coincident with diets that were found to be entirely plant based to heavily annual based respectively[4,5].

Many elements are essential in relative quantity, they are usually called "bulk minerals". Some are structural, but many play a role as electrolytes [6]. Nitrogen, phosphorus and potassium have great effects in plant growth and development. Their deficiencies or excesses result in marked effects on the growth and yield of crops. Nitrogen is a chlorophyll component and it promotes vegetative growth and green colouration of foliage [7]. Phosphorus plays a major role in photosynthesis,respiration, energy storage, cell division and maturation. Potassium is important in plant metabolism, protein synthesis and chlorophyll development [8]. Calcium regulates transport of other nutrients and also involved in the activation of certain plant enzymes, its deficiency results in stunting. Umebese [9]] reported the uptake of heavy metals by seeds of some legumes as negligible and it was as a result of the high accumulation of calcium by its seeds. African yam bean is a lesser known and underexploited species [10 14].

In Nigeria, the African yam bean is known as "Otili" in Yoruba land and typifies a neglected traditional crop. There is no record indicating when it entered into cultivation. But, for several decades now it has been cultivated and maintained by traditional farmers but has not received any attention from researchers. African yam bean is distributed throughout most tropical Africa [2, 15]. It is found in forests, open and wooded grasslands, rocky fields as well as marshy grounds, occurring both as weed and a cultivated crop $[2,16]$. It grows on a wild range of soils including acid and highly leached sandy soils at altitudes from sea level to $1,950 \mathrm{~m}[15,16]$. A number of farmers visited cultivate this crop because it is free from pests and diseases commonly encountered with cowpea and groundnut. Besides, the pods do not shatter easily, giving 
them the flexibility to make harvests as the need arises. Finally, it suffers less damage in storage compared to cowpea. Their main problem is long hours required in cooking.

African yam been have been reported in Nigeria [10, 12, 17-22] but none of these researchers studied it in a region where chicken are being reared.

\subsection{Aim}

This research work therefore looks into the levels of macronutrients in the soil, leaves and seeds of African yam bean around poultry farm environment.

\subsection{Study area}

The study area was in Ede (latitude $7^{\circ} 44.952^{\prime} \mathrm{N}$ and longititude $4^{\circ} 26.114^{\prime} \mathrm{E}$ ), Osun state Nigeria with an elevation of $271.8 \mathrm{~m}$ above sea level. The site used for the study was a poultry farm.

\subsection{Sample collection/ preparation}

Three different samples were used for the study. These include soil, leaves, and seed of African yam bean collected at different points on the farm. Soil samples were collected in a labeled polythene bag. Leaves were also collected in a labeled polythene bag. The pods containing African yam bean were carefully removed to get the beans. These samples were taken to the laboratory and analyzed immediately for nitrogen, phosphorus, potassium, calcium and magnesium contents.

\subsection{Sample analysis}

$10.0 \mathrm{~g}$ of ground leaves and bean seed were weighed into a porcelain crucible and ignited in a murfle furnace for five hours. $50 \mathrm{ml} 1 \mathrm{~N} \mathrm{HCl}$ was added to $0.2 \mathrm{~g}$ of ash obtained from this and then digested. This was filtered and made up with distilled water. $0.2 \mathrm{~g}$ of soil sample was weighed into a crucible and digested with $50 \mathrm{ml} 1 \mathrm{~N} \mathrm{HCl}$, filtered and made up with distilled water. Standard solutions of the metals $(\mathrm{K}, \mathrm{Ca}$ and $\mathrm{Mg}$ ) were prepared for calibration. The resulting absorbance of the calcium and magnesium were determined from the calibration graph and concentration recorded as $\mathrm{mg} / \mathrm{kg}$ of metal using atomic absorption spectrophotometer (BUCK 210 VGP). Phosphorus was determined in the samples collected colorimetrically using Vanado-molybdate method. Nitrogen in the samples collected was determined by Kjeldahl method. The percentage nitrogen was then determined by distillation using $40 \% \mathrm{NaOH}$ and $4 \%$ boric acid. It was then titrated against $0.01 \mathrm{~N} \mathrm{HCl}$.

\subsection{Statistical analysis}

All analyses were carried out in triplicates $(n=3)$ and results recorded in averages. Using a one-way classification, analysis of variance (ANOVA) of the means of macronutrients in soil, leaves, and seeds was done to test the level of significance at $\mathrm{p}<0.05$. Pearson correlation was also performed to see level of association between the parameters using STATISTICAL 7.

\section{Results and Discussion}

The results of the analysis of macronutrients obtained are as shown in tables 1-3.Table 1 illustrates level of macronutrients in soil used in planting African yam bean. Table 2 illustrates the level of macronutrients in leaves of African yam bean and table 3 shows the levels of macronutrients in seeds of African yam bean.

Table 1 illustrates the level of macronutrients in soil. The nitrogen level here $(0.245 \pm 0.12 \%)$ was lower compared to what was obtained in table 2 and 3 . The highest nitrogen content was obtained in table 2 and 3.The highest nitrogen content was obtained in African yam bean seed. This can be as a result of the chicken manure present

Table 1: Macronutrient composition of the soil of African yam bean (Sphenostylis sternocarpa Harms)

\begin{tabular}{ll}
\hline Macronutrient & Mean \pm SD \\
\hline Nitrogen & $0.245 \pm 0.12 \%$ \\
Phosphorus & $334 \pm 10 \mathrm{mg} / \mathrm{kg}$
\end{tabular}


Potassium

Calcium

Magnesium
$6644 \pm 13 \mathrm{mg} / \mathrm{kg}$

$1738 \pm 15 \mathrm{mg} / \mathrm{kg}$

$752 \pm 13 \mathrm{mg} / \mathrm{kg}$

Table 2: Macronutrient composition of leaves of African yam bean (Sphenostylis sternocarpa Harms)

\begin{tabular}{lc}
\hline Macronutrient & Mean $\pm \mathrm{SD}$ \\
\hline Nitrogen & $2.01 \%$ \\
Phosphorus & $294 \pm 10 \mathrm{mg} / \mathrm{kg}$ \\
Potassium & $11056 \pm 10 \mathrm{mg} / \mathrm{kg}$ \\
Calcium & $6576 \pm 19 \mathrm{mg} / \mathrm{kg}$ \\
Magnesium & $1547 \pm 30 \mathrm{mg} / \mathrm{kg}$ \\
\hline
\end{tabular}

in the soil for nutrient supplement. Potassium was very high in leaves analyzed according to table 2 . Potassium obtained in the mature seed in table 3 was very low compared to what was obtained in other tables. This might be attributed to the fact that on the site where the samples were collected, poultry manure are not being disposed here and so might contribute to the low level of phosphorus in this site. Calcium regulates transport of other nutrients and this explains why its level was highest in the leaves of African yam bean as shown in table $2(6576 \pm 19 \mathrm{mg} / \mathrm{kg})$. The lowest level of calcium was obtained in the mature seed in table $3(460 \pm 4 \mathrm{mg} / \mathrm{kg})$. Concentration of magnesium was highest in the leaves of African yam bean seed as shown in table 2. The absorption of metals in plants depends on the degree of the element dilution, which is related to the physical and chemical properties of the soil [23,24]. Nutrients uptake in the soil is achieved by cation exchange, wherein root hairs pump hydrogen ions $\left(\mathrm{H}^{+}\right)$into the soil through proton pumps. These hydrogen ions displace cation attached to negatively charged soil particles so that the cations are available for uptake by the root.

Table 3: Macronutrient composition of seed of African yam bean (Sphenostylis sternocarpa Harms)

\begin{tabular}{ll}
\hline Macronutrient & Mean \pm SD \\
\hline Nitrogen & $3.37 \pm 0.26 \%$ \\
Phosphorus & $75.5 \pm 2.1 \mathrm{mg} / \mathrm{kg}$ \\
Potassium & $2422 \pm 11 \mathrm{mg} / \mathrm{kg}$ \\
Calcium & $460 \pm 4 \mathrm{mg} / \mathrm{kg}$ \\
Magnesium & $1101 \pm 5 \mathrm{mg} / \mathrm{kg}$ \\
\hline
\end{tabular}

Nitrogen in this study compares well with what was obtained by [25]. The levels of phosphorus, potassium, calcium and magnesium in this study were higher compared to what was obtained by [25] and [26] and this might be because of the environment where the soil was obtained. The nature of environment had a great impact on the composition of soil samples analyzed.

Table 4: Pearson correlation between pairs of macronutrients in soil, leaves, and seed

\begin{tabular}{|c|c|}
\hline Macronutrient pairs & Pearson correlation \\
\hline $\mathrm{N}_{\text {soil/ }} \mathrm{N}_{\text {leaves }}$ & $\mathrm{r}=-0.490$ \\
\hline $\mathrm{N}_{\text {leaves }} / \mathrm{N}_{\text {seed }}$ & $r=-0.545$ \\
\hline $\mathrm{N}_{\text {soil }} / \mathrm{N}_{\text {seed }}$ & $r=0.365$ \\
\hline $\mathrm{P}_{\text {soil }} / \mathrm{P}_{\text {leaves }}$ & $r=-0.925$ \\
\hline $\mathrm{P}_{\text {leaves }} / \mathrm{P}_{\text {seed }}$ & $r=0.614$ \\
\hline $\mathrm{P}_{\text {soil }} / \mathrm{P}_{\text {seed }}$ & $r=-0.466$ \\
\hline $\mathrm{K}_{\text {soil }} / \mathrm{K}_{\text {leaves }}$ & $r=-0.767$ \\
\hline $\mathrm{K}_{\text {leaves }} / \mathrm{K}_{\text {seed }}$ & $\mathrm{r}=0.355$ \\
\hline $\mathrm{K}_{\text {soil } /} \mathrm{K}_{\text {seed }}$ & $r=-0.479$ \\
\hline $\mathrm{Ca}_{\text {soil }} / \mathrm{Ca}_{\text {leaves }}$ & $\mathrm{r}=0.561$ \\
\hline$\overline{\mathrm{Ca}} a_{\text {leaves/ }} \mathrm{Ca}_{\text {seed }}$ & $r=-0.385$ \\
\hline $\mathrm{Ca}_{\text {soil/ }} \mathrm{Ca}_{\text {seed }}$ & $r=-0.385$ \\
\hline $\mathrm{Mg}_{\text {soil } /} \mathrm{Mg} \mathrm{l}_{\text {eaves }}$ & $r=-0.287$ \\
\hline $\mathrm{Mg}_{\text {leaves }} / \mathrm{Mg}_{\text {seed }}$ & $\mathrm{r}=0.900$ \\
\hline $\mathrm{Mg}_{\text {soil }} / \mathrm{Mg}_{\text {seed }}$ & $r=-0.183$ \\
\hline $\mathrm{N}_{\text {soil }} / \mathrm{K}_{\text {seed }}$ & $r=0.901$ \\
\hline
\end{tabular}


$\mathrm{N}_{\text {soil } / \mathrm{Mg} \text { soil }} \quad \mathrm{r}=0.943$

$\mathrm{N}_{\text {leaves }} / \mathrm{P}_{\text {soil }} \quad \mathrm{r}=0.860$

\subsection{Statistical analysis}

Statistical analysis reveals a significant difference in means of macronutrients obtained for soil, leaves and seeds of African yam beans using one-way analysis of variance(ANOVA) at $p<0.05$. Significant positive correlation was observed between some macronutrients signifying that there is a kind of association between these macronutrients, this is as shown in table 4 and this include $\mathrm{N}_{\text {soil }} / \mathrm{K}_{\text {seed }}(\mathrm{r}=0.901), \mathrm{N}_{\text {soil }} / \mathrm{Mg}$ soil $(r=0.943), N_{\text {leaves }} / P_{\text {soil }}(r=0.860)$. Some negative correlations were also noticed between some of the pairs implying that that there is no positive correlation between them as shown in table 5. Positive correlation was observed for macronutrients in leaves/seed compared to soil/leaves and soil/seed except for $\mathrm{N}_{\text {leaves }} / \mathrm{N}_{\text {seed }}$ with negative correlation $(r=-0.545)$. The reason for the positive correlation between leaves and seed might be because both the seed and leaves get most of their nutrient from the soil and air. Plants uptake essential elements from the soil through their roots and from the air (through their leaves).

\section{Conclusion and Recommendation}

Sphenostylis stenocarpa is a less utilized crop in Nigeria. The leaves of African yam bean can also be consumed by both human beings and animals since it can also be used as fodder for livestock which makes the overall value of the plant even greater. Very little percentage of the population makes use of this crop as a good source of macronutrients. Most people prefer other cowpea to this legume. The study reveals higher macronutrients levels in soil and leaves of African yam bean as compared to the seed, which is edible but takes longer time to cook. Highest priority should be given to reduction of cooking time, which was cited as the main problem by farmers. Indeed the African yam bean has a potential role in contributing to national food security when developed to such an extent that it becomes accepted nationwide as a component of some popular meals. There is evidence that the crop produces as much seed per unit area as cowpea (the most popular tropical legume) or winged bean (a promising tropical legume).

\section{Acknowledgments}

The authors appreciate the Osun State Polytechnic, Iree. Nigeria for providing the facilities used for the research work. We are also grateful to all the technologists for their assistance.

\section{References}

[1] G.Y.P. Klu, H.M. Amoatey, D. Bansa, and E.K.. Kumaya, Cultivation and use of African Yam Bean Sphenostylis stenocarpa in the Volta region of Ghana. Plant Genet. Newleft. 124, 2000, 13-16.

[2] D. Potter, Economic botany of Sphenostylis stenocarpa (Leguminosae). Econ. Bot. 46, 1992, 262-275.

[3] D.E.C. Corbridge, Phosphorous : An Outline of its Chemistry, Biochemistry and Technology, 5th ed. Elsevier Amsterdam. ISBN 0-444-89307-5, 1995.

[4] T. Campbell, and T. Campbell, The China study. Dallas Benella Books. ISBN 1932100385, 2005.

[5] S.E. Lakhan, and K.F. Vieira, Nutrition therapies for mental disorders. Nutri. J.7:2.doi:10.1186/1475-2891-7-2.PMID 18208598. PMC 2248201. http://www.nutritionJ. Com/content/7/1/2, 2008.

[6] D.L. Nelson, and M.M. Cox, Lehninger Principles of Biochemiatry,3rd ed. Worth Publishing, New York ISBN 1-57259-1536, 2000.

[7] J.B. Jones, A guide for the hydroponic and soil-less culture grower. Timber Press, Beaverton, Oregon, $1983,124$.

[8] S.U. Reminson, Basic principles of crop physiology. Sadoh Press Nig. Limited. Benin City. $2005,170$.

[9] C.E Umebese, and Ade- O.E. Ademilua, and B.O . Olonisakin, Impact of combined industrial effluent on metal accumulation, nitrate reductase activity and yield of two cultivars of vigna unguiculata (L.) walp. J. Environ. Sci. Technol., 2, 2009, 146152.

[10] K.O. Rachie, and L.M. Roberts, Grain legumes of the lowland tropics. Advances in Agronomy. 26, 1974, 1-32.

[11] D.O. Edem, C.I. Amugo, and O.U. Eka, Chemical composition of yam bean ( Sphenostylis stenocarpa). Tropical Science. 30, $1990,59-63$. 
[12] E. Ene-Obong , and F.I. Okoye, Interrelationships between yield and field components in the African yam bean Sphenostylis stenocarpa (Hochst ex A. rich.)Harms. Beitrage zur tropischen Land W irtshaft und veterinarmedizin 30(3) 1992, $283-290$.

[13] S.O. Bennett- Lartey, F. K. Ayensu, S. Mohma, and K. Ho, Vegetable germplasm collection in Ghana. Plant Genetic Resources, Newsleter 111, 1997, 69-71.

[14] H.M. Amoatey, S.O. Bennett-Lartey, and D.K. Gamedoagbao, Conservation and improvement of neglected traditional food crop in Ghana using induced mutation techniques. Paper presented at AFRA planning workshop on improvement and rehabilitation of traditional and neglected food crops through mutation techniques, Pretoria, $24^{\text {th }}-28^{\text {th }}$ November $9,1997$.

[15] Anonymous, U.S. Environmental Protection Agency environmental agency test- methods for the evaluating solid waste, SW$846,1995$.

[16] J.A. Duke and B.N. Okigbo and C.F. Reed, African yam bean, Sphenostylis sternocarpa (Hochst ex A. Rich), Tropical Grain Legume Bulletin. 10, 1977, 4-5.

[17] M.I. Ezueh, The African yam bean as a crop in Nigeria, World Crops. 36(6), 1977, 199-200.

[18] M.I. Ezueh, The cultication and utilization of minor food legumes in Nigeria. Tropical Grain Legume Bulletin . 10, 1984, 2832.

[19] E.O. Nwachukwu, and C.I. Umechuruba, Seed- borne fungi associated with African yam bean seeds in four eastern states of Nigeria. Seed Resaerch . 19, 1991, 13-20.

[20] T. I. Ofuya, and K. A. Bamgbola, Damage potential, growth, and development of the seed beetle, callsbruchus maculates on some tropical legumes. Tropical Agriculture. 68(1), 1991, 33-36.

[21] I.C. Obizoba, and N. Nnam, The effects of sprouting times on nutrition value of two varieties of African yam bean (Sphenostylis stenocarpa). Plant-foods-for-Human- Nutirtion. 42 (4), 1992, 319-327.

[22] A.A. Oshodi, E.I. Adeyeye, and K.O. Ipinmoroti,. Functional properties of some varieties of African yam bean ( Sphenostylis sternocarpa) flour. International Journal of Food Science and Nutrition. 45 (2), 1994, 115-126.

[23] M.M. Lasat, The use of plants for the removal of Zealand toxic metals from contaminated soils. 2002011154, U.S.

[24] B.H. Robinson, The phytoextraction of metals from metalliferous soils, doctoral diss. Massy University, New Zealand, 1997.

[25] G.C. Mgbeze, and Y. Abu, The effects of NPK and farmyard manure on the growth and development of African yam bean ( Sphenostylis stenocarpa Hochst ex. a rich), African Journal of Biotechnology. 9 (3), 2010, 6085-6090.

[26] D. F. Apata, and O. Ologhobo, Some aspects of biochemistry and antioxidant value of African yam bean seed. (Sphenostylis stenocarpa) Food Chemistry, 36 (4), 1990, $271-280$. 